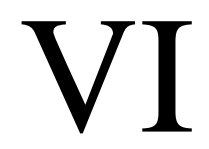

Phylogenetic relationship of Arthrospira, Phormidium, and Spirulina strains from Kenyan and Indian waterbodies 


\title{
Phylogenetic relationship of Arthrospira, Phormidium and Spirulina strains from Kenyan and Indian waterbodies
}

\begin{abstract}
Morphological and genetic diversity of cultured cynobacterial strains of species of the genera Arthrospira, Spirulina and Phormidium from two geographically different regions and habitats (Kenyan saline-alkaline lakes and Indian freshwater bodies) were investigated. Light microscopy observations were used to determine morphological diversity of the cyanobacteria. Three independent molecular techniques, sequencing of $16 \mathrm{~S}$ rRNA gene, internally transcribed spacer region between $16 \mathrm{~S}$ and $23 \mathrm{~S}$ rDNA (ITS) and the phycocyanin locus (PC-IGS) were conducted for the examination of phylogenetic relationship. Despite differences in morphology and habitats the Kenyan and Indian Arthrospira strains belong to the same cluster in phylogenetic trees of the 16S rDNA (AY575923-AY575932) or PC-IGS (AY575937-AY575946). The DNA similarity in both methods was 100\%. In the ITS tree, the two Indian Arthrospira strains PD1998/pus (AY575930) and PD2002/ana (AY575932) form their own sub-cluster. The Phormidium strain AB2002/07 (AY575933) from Lake Nakuru, Kenya is included in the Arthrospira cluster in the ITS tree and very closely related in the $16 \mathrm{~S}$ and PC-IGS trees. Based on 16S rDNA and PC-IGS phylogeny the sequences of the Spirulina strains form a separate cluster distinct from the Arthrospira cluster. The Kenyan and Indian Spirulina subsalsa strains show a considerable genetic variability as similarities in 16S rRNA gene sequence is $91.5 \%$ only. Molecular characterizations of cyanobacterial strains in the present study demonstrate that several distinct morphotypes may be genetically similar and vice versa.
\end{abstract}

Key words: Arthrospira, Cyanophyceae, morphology, Phormidium, phylogeny, Spirulina

\section{Introduction}

The species and genus concept of cyanobacteria is changing from the traditional morphological classification to a concept using different phenotypic features (e.g. biochemical and ultrastructural characteristics) and genotypic features (ANAGNOSTIDIS \& KomáreK 1985, 1988, CAstenholz et al. 2001, Wilmotte \& Herdman 2001). For phylogenetic analyses of bacteria and cyanobacteria one of the most informative genes is the 16S rRNA gene (Woese 1987, OlsEn \& WoEse 1993, Ludwig \& SCHLEIFER, 1994, Ludwig 
\& KLENK 2001). The 16S rRNA gene has a conserved function and is universally present in bacteria and cyanobacteria. The phylogenetic investigations using $16 \mathrm{~S}$ sequences have shown that many unicellular and filamentous non heterocysteous cyanobacterial genera are probably polyphyletic and can not be grouped as natural taxa, whereas heterocysteous strains form a monophyletic group (GIOvAnNONI et al. 1988, Wilmotte 1994, CASTENHOLZ et al. 2001, RIPPKA et al. 2001, WILMOTTE \& HERDMAN 2001). As the number of variable positions is low in the $16 \mathrm{~S}$ rDNA, it is not very useful for studying the relationship on the species level or below it. For this purpose other more variable non-coding sequences like the internal transcribed spacer region of the $16 \mathrm{~S}-23 \mathrm{~S}$ region (ITS) or the intergenic spacer of the phycocyanin operon between $\mathrm{cpcB}$ and cpcA subunit (PC-IGS) have been introduced (NEILAn et al. 1995, Boyer et al. 2001, BAURAin et al. 2002, MANEN \& FALQUET 2002).

In the case of the genera Arthrospira and Spirulina, which were merged by GEITLER (1932), several morphological studies have shown differences between the genera e.g. in helicity, trichome size, cross wall, cell wall structure, pore pattern and gas vesicles (DESIKACHARY 1959, HindÁK 1985, Guglielmi and CoHEN-BAZIRE 1982a, 1982b, GuGLIELMI et al. 1993, TOMASELLI et al. 1996, 1997). Investigations of the conserved 16S rRNA gene and the more variable PC-IGS revealed that Arthrospira is not closely related to Spirulina (NELISSEN et al. 1994, Nelissen et al. 1996, MANen \& FAlquet 2002, Litvaitis 2002). The separation of these two genera has been accepted in Bergey's Manual of Systematic Bacteriology (CAstenholz 1989, Castenholz et al. 2001).

Using amplified ribosomal DNA restriction analysis (ARDRA), ITS analysis and the PC-IGS several Arthrospira strains from four continents assigned to four different species (Arthrospira fusiformis (VOROCHININ) KOMÁREK \& LUND, A. platensis (NORDSTEDT) Gomont, A. maxima SeTChel \& GARDNER, and A. indica DesikACHARY \& JEEJI-BAi could be distinguished in different clusters (SCHELDEMAN et al. 1999, BAURAIN et al. 2002, MANEN $\&$ FALQUET 2002). No relationship was detected between the clusters and the geographic origin of the strains and their morphology.

The aim of this study is to examine the phylogenetic relationship among Arthrospira, Spirulina and Phormidium strains from seven Kenyan alkaline-saline habitats and four Indian freshwater habitats. For the investigation a polyphasic approach including morphological characters and sequence analysis of 16S rRNA gene, ITS region and PC-IGS locus is applied. 


\section{Materials and Methods}

\section{Organisms and culture conditions}

Strains of Arthrospira, Phormidium, and Spirulina were isolated from water samples from Kenyan and Indian water bodies. The strains of cyanobacteria investigated in this study and their origin are listed in Table 1. They were determined according to HINDÁK $(1985,2001)$ and DESIKACHARY \& JEEJI BAI $(1992,1996)$.

Using a microcapillary a single trichome was isolated, washed and placed in capped tubes containing $10 \mathrm{~mL}$ culture medium. The Kenyan cyanobacterial strains were cultivated in Bourrelly medium (HEGEWALD et al. 1994) modified with an addition of $0.3 \mathrm{~g} \mathrm{~L}^{-1} \mathrm{Na}_{2} \mathrm{CO}_{3}$ and $15 \mathrm{~g} \mathrm{~L}^{-1} \mathrm{NaCl}$. The Indian Arthrospira strains were grown in Spirulina medium (SCHLÖSSER 1994) modified from AIBA \& OGAWA (1977). The Indian Spirulina strain was cultured in BG-11 medium (RIPPKA et al. 1979). All strains investigated in this study were maintained at $18{ }^{\circ} \mathrm{C}$ with a photon flux density of $20 \mu \mathrm{mol}$ of photon $\mathrm{m}^{-2} \mathrm{~s}^{-1}$ (equivalent to 1500 lux). Morphological observations were made using a Nikon Optiphot 2 light microscope (Nikon, Tokyo, Japan).

\section{Genomic DNA Extraction}

Fresh cell material was centrifuged. After discarding the supernatant, the genomic DNA was extracted and purified using Dynabeads DNA DIRECT System I (Deutsche Dynal GmbH, Hamburg, Germany).

\section{PCR Amplification and Sequencing}

PCR amplification was done using the Taq PCR Core Kit (Qiagen GmbH, Hilden, Germany) and a Peltier Thermal Cycler PTC 200 (MJ Research, Inc., San Francisco, USA). The reaction mixture contained $0.1 \mu \mathrm{l}$ Taq DNA polymerase (concentration 5 units per $\mu \mathrm{L}$ ), $0.6 \mu \mathrm{L}$ dNTP Mix (10 mM), $2 \mu \mathrm{L}$ buffer (10x concentrated, containing Tris $\mathrm{Cl}, \mathrm{KCl},\left(\mathrm{NH}_{4}\right)_{2} \mathrm{SO}_{4}$ and $15 \mathrm{mM}$ $\mathrm{MgCl}_{2}, 1 \mu \mathrm{L}$ forward primer $\left(10 \mathrm{pmol} \mu \mathrm{L}^{-1}\right), 1 \mu \mathrm{L}$ reverse primer $\left(10 \mathrm{pmol} \mu \mathrm{L}^{-1}\right)$ and $1 \mu \mathrm{L}$ genomic DNA in a total volume of $20 \mu \mathrm{L}$. Primers used for amplification of the $16 \mathrm{~S}$ rRNA gene, the ITS region and PC-IGS locus are listed in Table 2.

The following program was used for amplification of 16S-23S rDNA fragment, employing cyanobacterial specific forward primer CYA106F and 23S5' R reverse primer: $5 \mathrm{~min}$ at $94{ }^{\circ} \mathrm{C}$ for 1 cycle; 30 cycles of $30 \mathrm{~s}$ at $94{ }^{\circ} \mathrm{C} ; 30 \mathrm{~s}$ at $50{ }^{\circ} \mathrm{C} ; 1 \mathrm{~min}$ at $70^{\circ} \mathrm{C}$ and a final elongation step 
of $72{ }^{\circ} \mathrm{C}$ for $3 \mathrm{~min}$. For the PCR of the PC-IGS the primers cpc_arF and cpc_arR and the following program were used: $3 \mathrm{~min}$ at $94{ }^{\circ} \mathrm{C}$ for 1 cycle; 30 cycles of $20 \mathrm{~s}$ at $94{ }^{\circ} \mathrm{C} ; 30 \mathrm{~s}$ at 55 ${ }^{\circ} \mathrm{C} ; 1 \mathrm{~min}$ at $72^{\circ} \mathrm{C}$ with final elongation step of $72{ }^{\circ} \mathrm{C}$ for $5 \mathrm{~min}$. PCR products were visualised by standard agarose gel electrophoresis and ethidium bromide staining.

Amplified products of 16S rDNA, ITS, and PC-IGS were purified through GFX spin columns (Amersham Pharmacia Biotech, Freiburg, Germany). The purified product of 16S-23S rDNA was sequenced using CYA106F, 23S5'R and the internal primers F3, 683R = F3reverse, 1045F, 1066R, R4R, 16S3'F. Sequencing of the purified PC-IGS locus was done employing the same primers used for PCR amplification. For each PCR product both strands were sequenced on ABI 3100 Avant Genetic Analyzer using BigDye Terminator V.3.1 Cycle Sequencing Kit (Applied Biosystems, Applera Deutschland GmbH, Darmstadt, Germany).

The 16S rDNA, ITS, PC-IGS sequences obtained were submitted to GenBank (NCBI). The accession numbers are depicted in Table 1.

\section{Phylogenetic analysis}

Sequences of partial 16S rRNA gene, the ITS region (including parts of 16S rDNA, tRNA Ile, ITS, tRNA Ala and parts of 23S region) and parts of the PC-IGS locus (including parts of срcB subunit, IGS and cpcA subunit) were analysed for all the strains, except KR2003/25 where only $16 \mathrm{~S}$ rDNA was analysed. The sequences were submitted to the GenBank (NCBI) (Table 1). The sequence parts of all strains with highly variable and ambiguous regions and gaps, where a proper alignment was impossible, were excluded from the alignment. In the case of $16 \mathrm{~S}$ rDNA a set containing 1258 positions was used. ITS comprised 686 and PC-IGS 309 positions. In the $16 \mathrm{~S}$ tree Gloeobacter violaceaus (AF132790) was used as an outgroup, in the ITS tree the cyanelle of Cyanophora paradoxa KORSH. (M19493) and in the PC-IGS tree Cyanobacterium sp. (AJ401183). The sequences (16S rDNA, ITS, PC-IGS) were aligned with other cyanobacterial sequences using MS Windows based Manual Sequence Alignment Editor (HEPPERLE 2002). The alignments are available from the authors on request. Fifty two (16S ribosomal DNA), 41 (PC-IGS locus) and 38 (ITS) sequences were considered for alignment and comparison including sequences taken from the National Center of Biotechnology Information, Rockeville (NCBI 2003). Phylogenetic analyses of aligned sequences were conducted using the ARB software package (http://www.arb-home.de). Phylogenetic trees were constructed by means of the maximum-likelihood algorithm using the fastDNAml program (FELSENSTEIN 1981, OLSEN et al. 1994). 


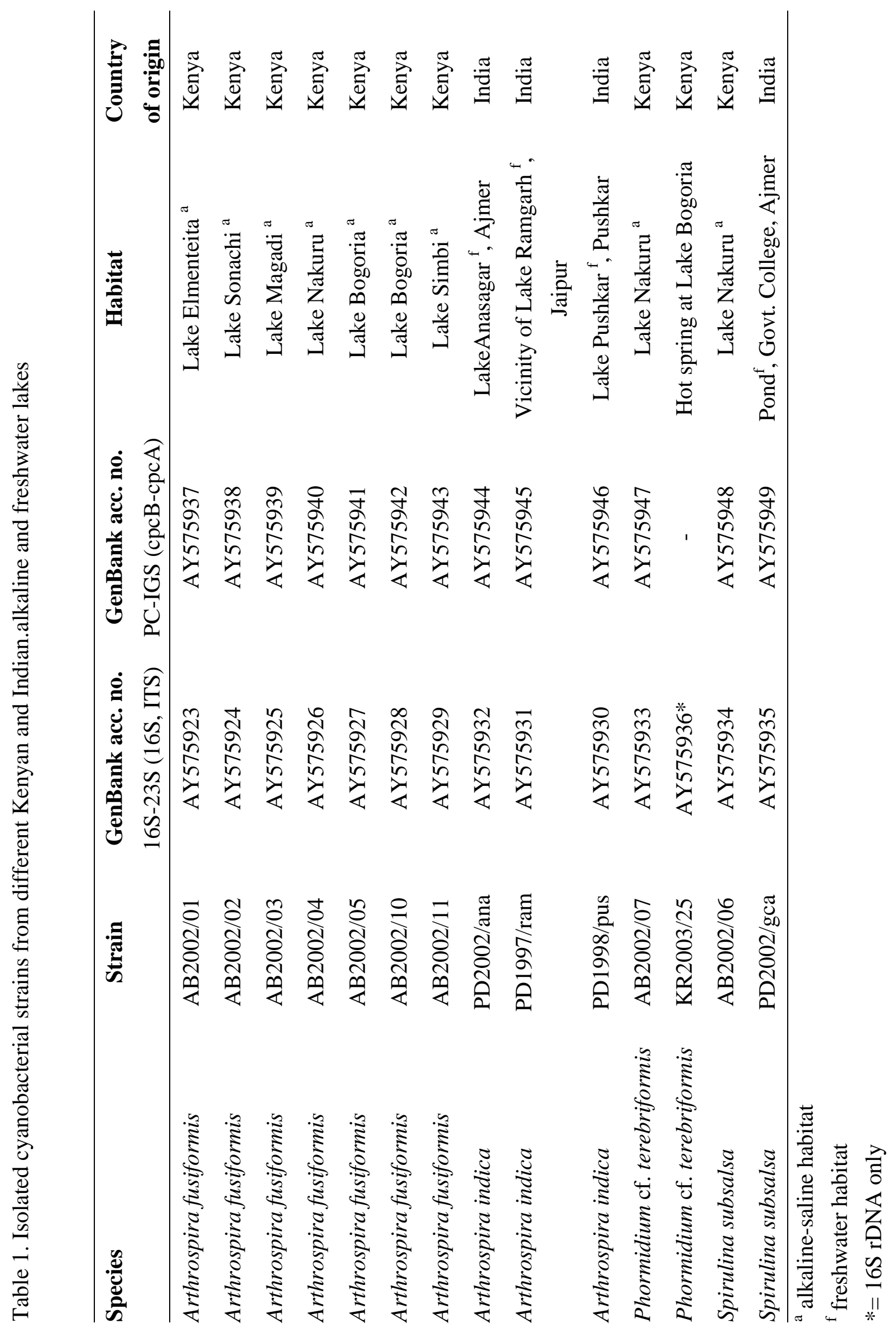


Table 2. Primers employed in the present study.

\begin{tabular}{|c|c|c|}
\hline Primers & Sequence (5'-3') & Reference \\
\hline \multicolumn{3}{|c|}{ 16S rRNA gene and } \\
\hline \multicolumn{3}{|l|}{ ITS region } \\
\hline CYA106F & TAACACATGCAAGTCGAA & $\begin{array}{l}\text { NÜBEL et al. } 1997 \text {, } \\
\text { LI et al. } 2001\end{array}$ \\
\hline F3 & GTGTAGCGGTGAAATGCGTAGA & Li et al. 2001 \\
\hline $1045 \mathrm{~F}$ & TGCCATCATTCAGTTGGGCAC & Newly designed \\
\hline $16 \mathrm{~S} 3{ }^{\prime} \mathrm{F}$ & TGTGGCTGGATCACCTCCTT & BAURAIN et al. 2002 \\
\hline $683 \mathrm{R}=\mathrm{F} 3$ reverse & TCTACGCATTTCACCGCTACAC & Li et al. 2001 \\
\hline 1066R & GTGCCCAACTGAATGATGGCA & Newly designed \\
\hline $\mathrm{R} 4 \mathrm{R}$ & TACGGCTACCTTGTTACGAC & Li et al. 2001 \\
\hline 23S5'R & TCTGTGTGCCTAGGTATCCACCGTT & BAURAIN et al. 2002 \\
\hline \multicolumn{3}{|c|}{ Phycocyanin Locus } \\
\hline \multicolumn{3}{|l|}{ (PC-IGS) } \\
\hline cpc_arF & TCGAAGATCGTTGCTTGAACG & Newly designed \\
\hline cpc_arR & TTAGGTCCCTGCATT TGGGTG & Newly designed \\
\hline
\end{tabular}

\section{Results}

Ten strains of Arthrospira spp., two strains of Spirulina spp. and two strains of Phormidium sp. isolated from seven Kenyan alkaline and four Indian freshwater habitats were cultivated and investigated for their morphological characteristics and their phylogenetic relationship. The morphological characteristics of the cultivated cyanobacterial strains are depicted in Table 3. For the phycological identification of Arthrospira, morphological features mainly width of trichome, cell size, nature and shape of helix, gas vesicles and calyptra on the end cells were taken into account. On the basis of morphological features observed in light microscope, the Kenyan Arthrospira strains were identified as A. fusiformis and the Phormidium strains were designated as $P$. cf. terebriformis (AGHARDH ex GOMONT) ANAGNOSTIDIS \& KomÁreK. All Indian Arthrospira strains corresponded to A. indica. Kenyan and Indian Spirulina strains were assigned to $S$. subsalsa Oersted. Species that were distinguished in the present study are illustrated in Fig. 1. 
Table 3. Morphological characteristics of different Arthrospira, Spirulina and Phormidium strains from Kenya and India.

\begin{tabular}{|c|c|c|c|c|c|c|}
\hline \multirow[t]{2}{*}{ Strain } & \multicolumn{6}{|c|}{ Characteristics } \\
\hline & $\begin{array}{c}\text { Width of } \\
\text { trichomes } \\
\quad(\mu \mathrm{m})\end{array}$ & $\begin{array}{c}\text { Cell } \\
\text { length } \\
(\mu \mathrm{m})\end{array}$ & $\begin{array}{c}\text { Calyptra } \\
\text { on end } \\
\text { cells }\end{array}$ & $\begin{array}{l}\text { Gas } \\
\text { vesicles }\end{array}$ & $\begin{array}{l}\text { Type of } \\
\text { coiling }\end{array}$ & $\begin{array}{l}\text { Shape of helix end } \\
\text { and end cell } \\
\text { morphology }\end{array}$ \\
\hline \multicolumn{7}{|c|}{ Arthrospira fusiformis } \\
\hline $\mathrm{AB} 2002 / 01$ & $8-9$ & $4-6$ & Absent & Present & Variable & Both ends rounded \\
\hline AB2002/02 & $8-15$ & $4-6$ & Absent & Present & $\begin{array}{c}\text { Variable, } \\
\text { straight }\end{array}$ & $\begin{array}{l}\text { One end of } \\
\text { trichome slightly } \\
\text { diminished }\end{array}$ \\
\hline AB2002/03 & 8 & $4-6$ & Absent & Present & Variable & $\begin{array}{l}\text { One end of } \\
\text { trichome slightly } \\
\text { diminished }\end{array}$ \\
\hline $\mathrm{AB} 2002 / 04$ & $4-10$ & $4-8$ & Absent & Present & $\begin{array}{c}\text { Very } \\
\text { variable }\end{array}$ & Both ends rounded \\
\hline AB2002/05 & $10-11$ & $4-8$ & Absent & Present & Variable & Both ends rounded \\
\hline AB2002/10 & $8-12$ & $4-6$ & Absent & Present & Variable & Both ends rounded \\
\hline $\mathrm{AB} 2002 / 11$ & $8-12$ & $4-5$ & Absent & Present & $\begin{array}{l}\text { Tightly } \\
\text { coiled }\end{array}$ & Both ends rounded \\
\hline
\end{tabular}

\section{Arthrospira indica}

PD2002/ana

8-9 6-8 Present Present Variable Slightly diminished at one end

PD1998/pus

6-8 6-8 Present Present Straight Slightly diminished

PD1997/ram

6-8 4-5 Present Present Variable Slightly diminished at one end

Phormidium cf. terebriformis

AB2002/07

6-7 3-5 Absent Absent Slightly Slightly diminished undulating at one end

KR2003/25

5-6 2-4 Absent Absent Straight to Slightly diminished slightly at both ends undulating

Spirulina subsalsa

AB2002/06

2-2.5 Septa not Absent Absent Regularly Both ends rounded visible coiled

PD 2002/gca

1.5-2.0 Septa not Absent Absent Regularly Both ends rounded visible coiled 

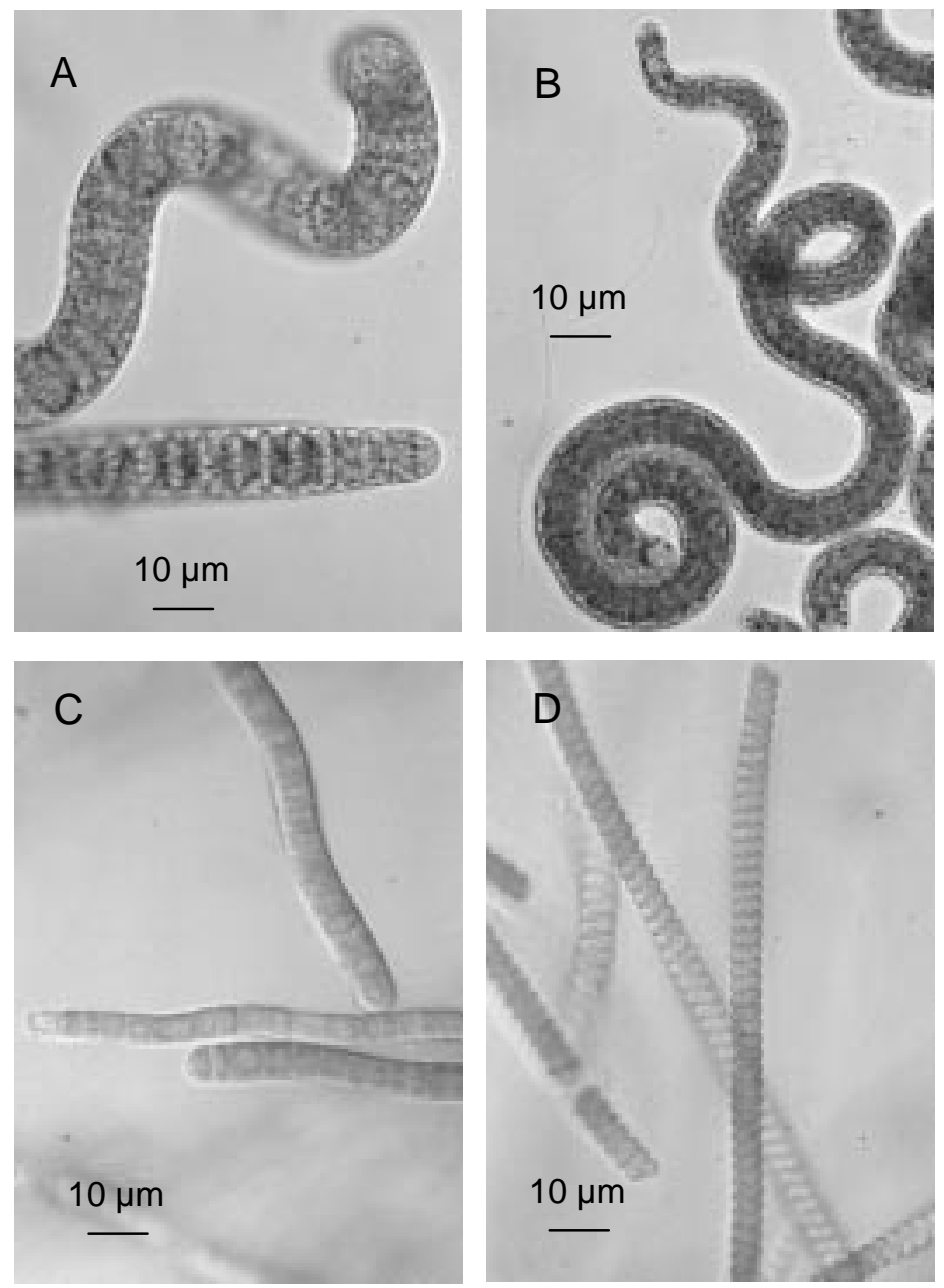

Fig. 1. A) Arthrospira fusiformis, B) Arthrospira indica, C) Phormidium cf. terebriformis, D) Spirulina subsalsa.

A phylogenetic tree of $16 \mathrm{~S}$ rDNA sequences of the Kenyan and Indian strains within a larger group of cyanobacteria is presented in Fig. 2. The $16 \mathrm{~S}$ tree showed a tight cluster of the Arthrospira strains (AY575923-AY575932) and a closely related Phormidium cf. terebriformis strain (AY575933). The whole cluster was supported by a bootstrap value of 99\%. Phormidium cf. terebriformis (AY575936) from the hot springs near Lake Bogoria was clearly separated from $P$. cf. terebriformis (AY575933) from Lake Nakuru. A closer relationship of the whole cluster to a cluster of Planktothrix and Oscillatoria spp. could be observed. This cluster was supported by a bootstrap value of $77 \%$. The Spirulina cluster was clearly separated from the Arthrospira cluster and was more related to Synechocystis sp. and Microcystis sp. (Fig 2). A comparison for the 16S rDNA nucleotides of the investigated strains in pairs is shown in Table 4. The seven Kenyan strains of Arthrospira fusiformis and the three Indian strains of $A$. indica had identical $16 \mathrm{~S}$ rDNA sequences at $100 \%$ similarity. 
The 16S rDNA sequence of Phormidium cf. terebriformis from Lake Nakuru (AY575933) had similarity of $99.6 \%$ with the Arthrospira sequences (Table 4). The 16S rDNA similarity between the two Phormidium sequences was only 92.0\% (Table 4).

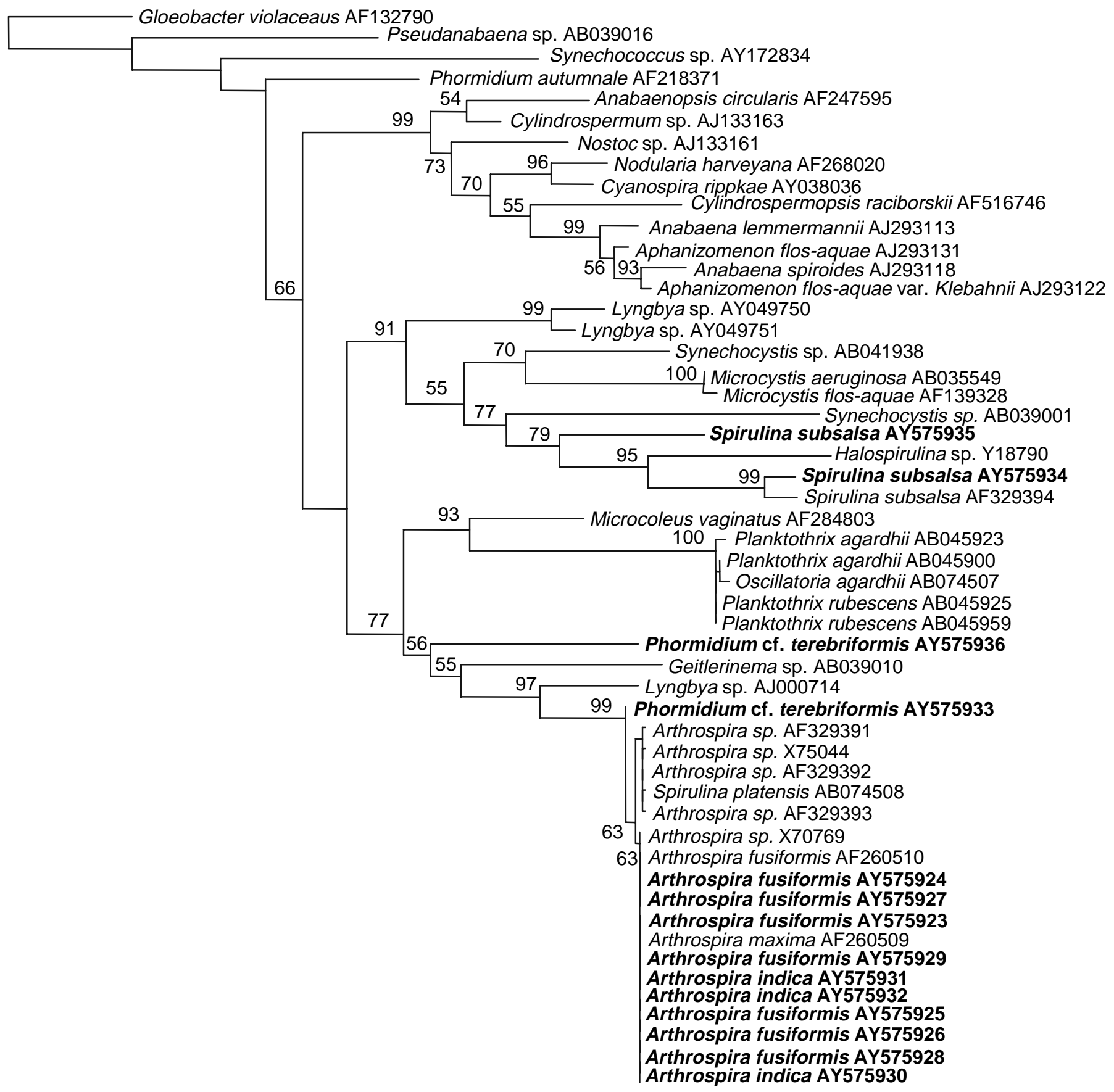

0.10

Fig. 2. Phylogenetic tree based on the alignment of partial $16 \mathrm{~S}$ sequences of 51 cyanobacterial strains. The tree was calculated using the maximum likelihood algorithm. Bootstrap values above $50 \%$ are included. Bar indicates $10 \%$ sequence divergence. 
Table 4. Calculated similarities between 16S rDNA sequences (1282 bp) of Arthrospira-, Phormidium- and Spirulina strains. The values in the upper right triangle are the percent identities between a pair of sequences. The values in the lower left triangle are the numbers of dissimilar nucleotides. For the related species name, see Table 1, AF260510 = Arthrospira fusiformis.

\begin{tabular}{|c|c|c|c|c|c|c|c|c|c|c|c|c|c|c|c|}
\hline & 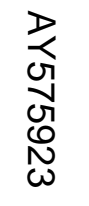 & 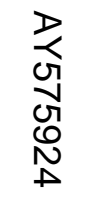 & 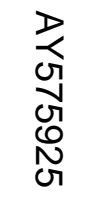 & 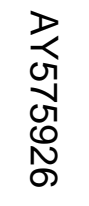 & 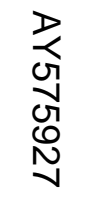 & 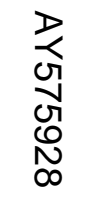 & 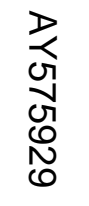 & 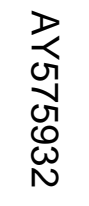 & 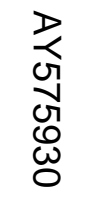 & 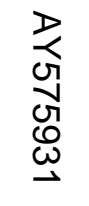 & 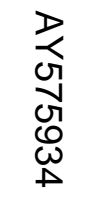 & 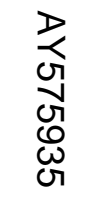 & 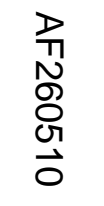 & 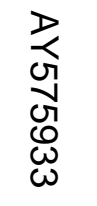 & 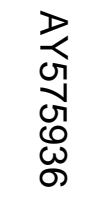 \\
\hline Y575923 & - & 100 & 100 & 100 & 100 & 100 & 100 & 100 & 100 & 100 & 89.9 & 90.5 & 100 & 99.6 & 92.3 \\
\hline AY575924 & 0 & - & 100 & 100 & 100 & 100 & 100 & 100 & 100 & 100 & 89.9 & 90.5 & 100 & 99.6 & 92.3 \\
\hline AY575925 & 0 & 0 & - & 100 & 100 & 100 & 100 & 100 & 100 & 100 & 89.9 & 90.5 & 100 & 99.6 & 92.3 \\
\hline AY575926 & 0 & 0 & 0 & - & 100 & 100 & 100 & 100 & 100 & 100 & 89.9 & 90.5 & 100 & 99.6 & 92.3 \\
\hline AY575927 & 0 & 0 & 0 & 0 & - & 100 & 100 & 100 & 100 & 100 & 89.9 & 90.5 & 100 & 99.6 & 92.3 \\
\hline AY575928 & 0 & 0 & 0 & 0 & 0 & - & 100 & 100 & 100 & 100 & 89.9 & 90.5 & 100 & 99.6 & 92.3 \\
\hline AY575929 & 0 & 0 & 0 & 0 & 0 & 0 & - & 100 & 100 & 100 & 89.9 & 90.5 & 100 & 99.6 & 92.3 \\
\hline AY575932 & 0 & 0 & 0 & 0 & 0 & 0 & 0 & - & 100 & 100 & 89.9 & 90.5 & 100 & 99.6 & 92.3 \\
\hline AY575930 & 0 & 0 & 0 & 0 & 0 & 0 & 0 & 0 & - & 100 & 89.9 & 90.5 & 100 & 99.6 & 92.3 \\
\hline AY575931 & 0 & 0 & 0 & 0 & 0 & 0 & 0 & 0 & 0 & & 89.9 & 90.5 & 100 & 99.6 & 92.3 \\
\hline AY575934 & 129 & 129 & 129 & 129 & 129 & 129 & 129 & 129 & 129 & 129 & - & 91.5 & 89.9 & 89.9 & 89.2 \\
\hline AY575935 & 122 & 122 & 122 & 122 & 122 & 122 & 122 & 122 & 122 & 122 & 109 & - & 90.5 & 90.3 & 88.4 \\
\hline AF260510 & 0 & 0 & 0 & 0 & 0 & 0 & 0 & 0 & 0 & 0 & 129 & 122 & - & 99.6 & 92.3 \\
\hline AY575933 & 5 & 5 & 5 & 5 & 5 & 5 & 5 & 5 & 5 & 5 & 130 & 124 & 5 & - & 92.0 \\
\hline AY575936 & 99 & 99 & 99 & 99 & 99 & 99 & 99 & 99 & 99 & 99 & 139 & 149 & 99 & 103 & \\
\hline
\end{tabular}

A phylogenetic tree for the PC-IGS region is represented mainly focusing on the sequences of Arthrospira and Spirulina strains (Fig. 3). A tight Arthrospira cluster was obtained, where Phormidium cf. terebriformis (AY575947) was closely related to. This was supported by a bootstrap value of $99 \%$. The Arthrospira cluster was divided into three subclusters. All Kenyan and Indian Arthrospira strains (AY575937-AY5759346) were located in one subcluster with a bootstrap value of $95 \%$. The similarity (455 bp) in the Kenyan and Indian 
Arthrospira sequences was $100 \%$ (Table 5). The Spirulina strains formed their own cluster relatively distant from the Arthrospira cluster.

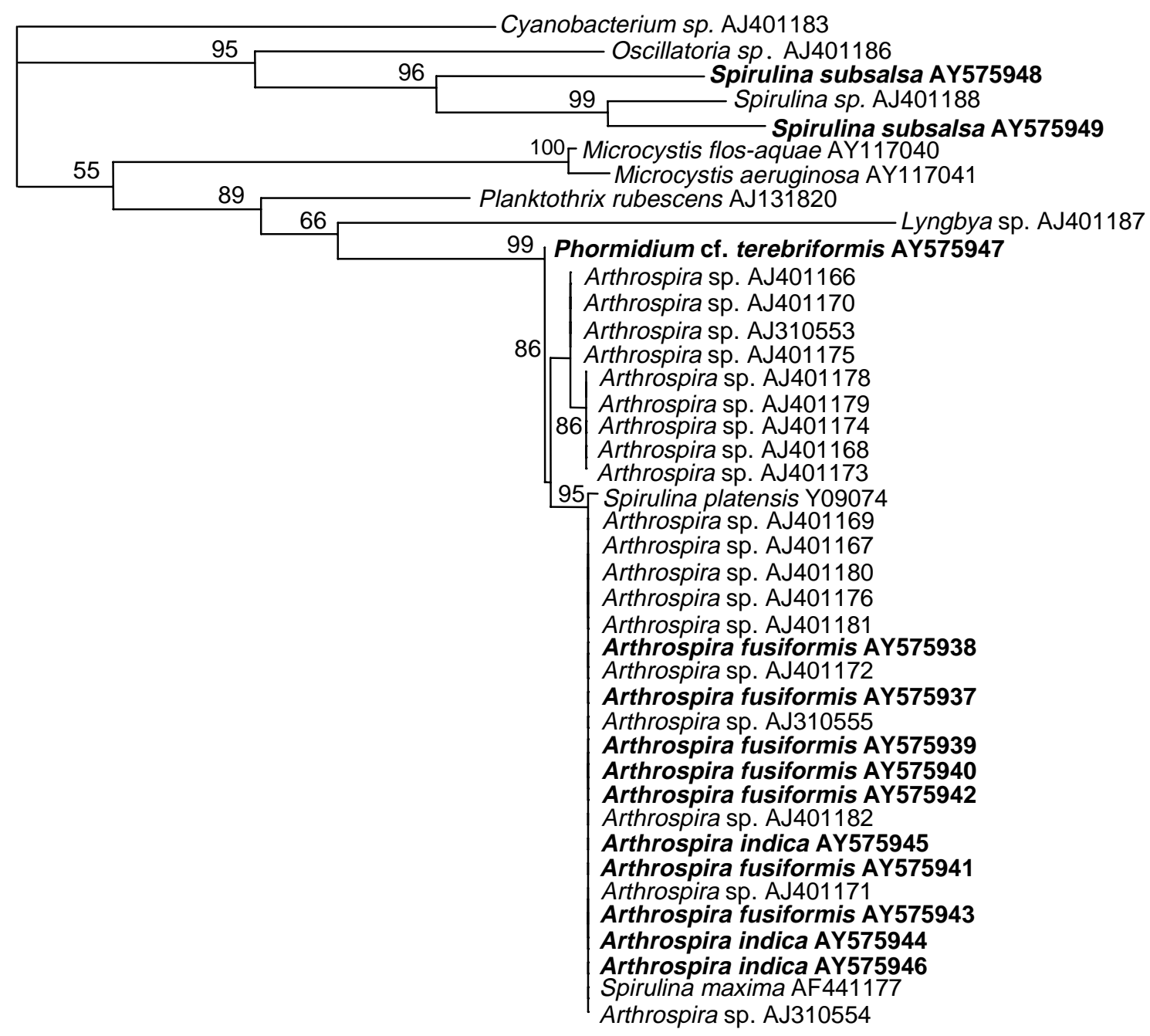

Fig. 3. Phylogenetic tree based on the alignment of sequences of the phycocyanin locus (PCIGS) of 41 cyanobacterial strains. The tree was calculated using the maximum likelihood algorithm. Bootstrap values $>50 \%$ are included. Bar indicates $10 \%$ sequence divergence. 
Table 5. Calculated DNA (455 bp) similarities in the phycocyanin operon (PC-IGS) between Arthrospira- and Phormidium strains. The values in the upper right triangle are the percent identities between a pair of sequences. The values in the lower left triangle are the numbers of dissimilar nucleotides. For the related species name, see Table 1.

\begin{tabular}{|c|c|c|c|c|c|c|c|c|c|c|c|}
\hline & 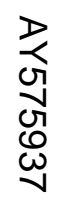 & $\begin{array}{l}\text { D } \\
\text { J } \\
\text { J } \\
\text { E్ } \\
\infty\end{array}$ & 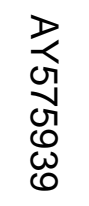 & 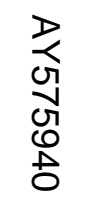 & 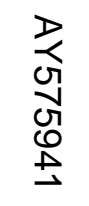 & 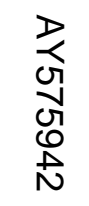 & 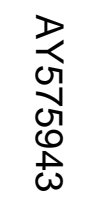 & 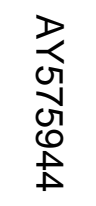 & 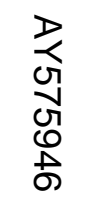 & $\begin{array}{l}\text { D } \\
\text { ज } \\
\text { U } \\
\text { ㅇ } \\
\text { जे }\end{array}$ & $\begin{array}{l}\text { D } \\
\text { G } \\
\text { J } \\
\text { E } \\
\text { v }\end{array}$ \\
\hline AY575937 & - & 100 & 100 & 100 & 100 & 100 & 100 & 100 & 100 & 100 & 98.0 \\
\hline AY575938 & 0 & - & 100 & 100 & 100 & 100 & 100 & 100 & 100 & 100 & 98.0 \\
\hline AY575939 & 0 & 0 & - & 100 & 100 & 100 & 100 & 100 & 100 & 100 & 98.0 \\
\hline AY575940 & 0 & 0 & 0 & - & 100 & 100 & 100 & 100 & 100 & 100 & 98.0 \\
\hline AY575941 & 0 & 0 & 0 & 0 & - & 100 & 100 & 100 & 100 & 100 & 98.0 \\
\hline AY575942 & 0 & 0 & 0 & 0 & 0 & - & 100 & 100 & 100 & 100 & 98.0 \\
\hline AY575943 & 0 & 0 & 0 & 0 & 0 & 0 & - & 100 & 100 & 100 & 98.0 \\
\hline AY575944 & 0 & 0 & 0 & 0 & 0 & 0 & 0 & - & 100 & 100 & 98.0 \\
\hline AY575946 & 0 & 0 & 0 & 0 & 0 & 0 & 0 & 0 & - & 100 & \\
\hline AY575945 & 0 & 0 & 0 & 0 & 0 & 0 & 0 & 0 & 0 & - & \\
\hline AY575947 & 9 & 9 & 9 & 9 & 9 & 9 & 9 & 9 & 9 & 9 & \\
\hline
\end{tabular}

The phylogenetic tree for the ITS focused only on strains of Arthropira spp. and Phormidium cf. terebriformis (Fig. 4). Four distinct subclusters were identified. The Kenyan Arthrospira (AY575923-AY575929) and Phormidium (AY575933) strains and the Indian A. indica strain PD1997/ram (AY575931) were collectively in one subcluster. The two Indian A. indica strains PD1998/pus (AY575930), PD2002/ana (AY575932) and A. indica (AJ292336) formed a second subcluster. The sequences of the remaining other Arthrospira strains constituted the two other subclusters. The similarity of the ITS sequences (470 bp) for the Kenyan Arthrospira strains and the Indian strain PD1997/ram was 100\%. The ITS sequences of the Indian strains PD1998/pus (AY575930) and PD2002/ana (AY575932) had similarity of $99.6 \%$ to sequences of the other investigated strains (Table 6). 
Cyanophora paradoxa M19493

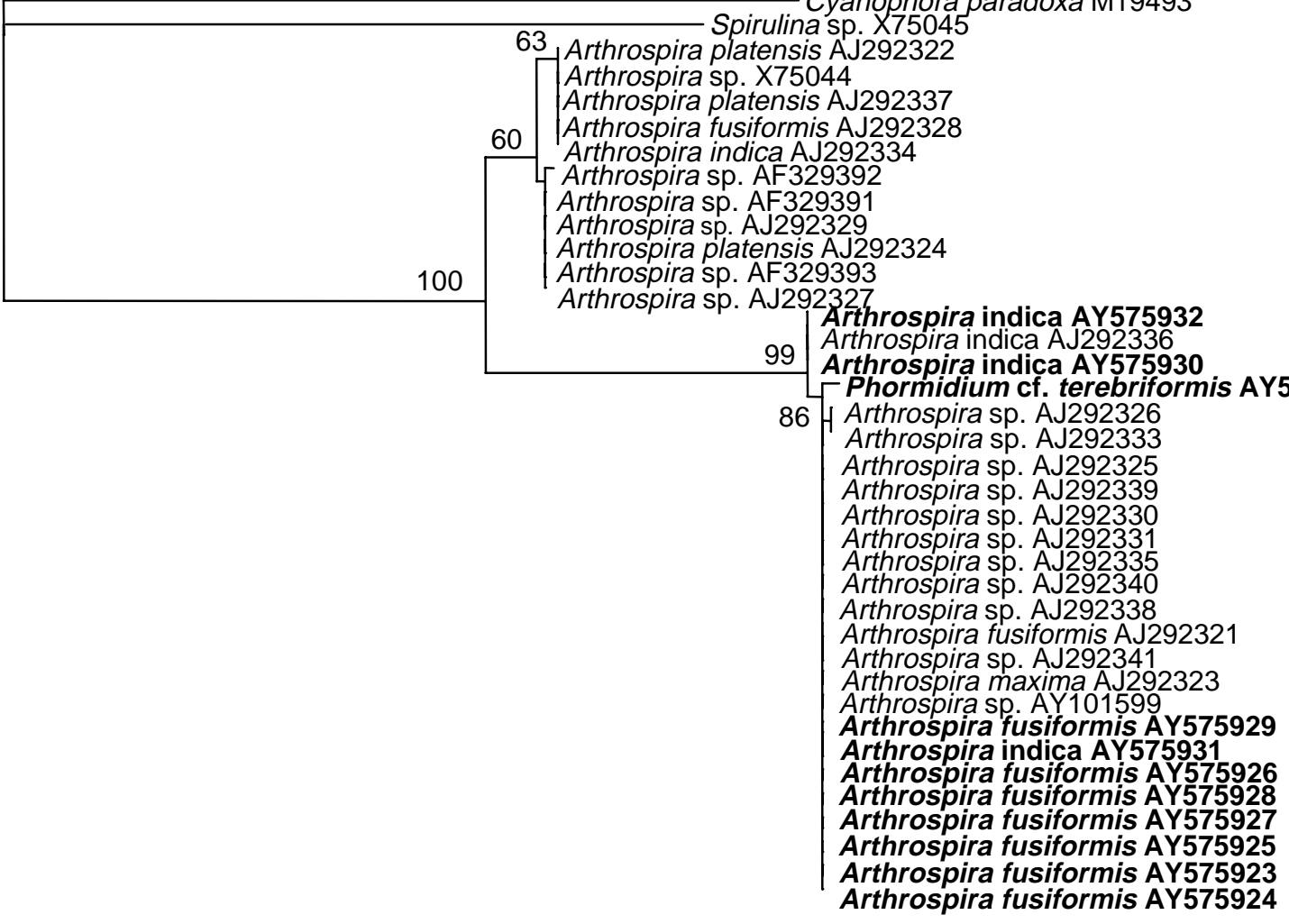

0.10

Fig. 4. Phylogenetic tree based on the alignment of sequences of the internally transcribed spacer region (ITS) of 38 cyanobacterial strains. The tree was calculated using the maximum likelihood algorithm. Bootstrap values > 50\% are included. Bar indicates $10 \%$ sequence divergence. 
Table 6. Calculated DNA similarities (470 bp) in the internally transcribed spacer region (ITS) between Arthrospira and Phormidium strains. The values in the upper right triangle are the percent identities between a pair of sequences. The values in the lower left triangle are the numbers of dissimilar nucleotides. For the related species name, see Table 1.

\begin{tabular}{|c|c|c|c|c|c|c|c|c|c|c|c|}
\hline & $\begin{array}{l}\text { ग } \\
\text { on } \\
\text { ज } \\
\mathbb{W} \\
\text { N }\end{array}$ & $\begin{array}{l}\text { D } \\
\text { on } \\
\text { U } \\
\text { N } \\
\text { N }\end{array}$ & 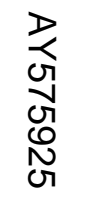 & $\begin{array}{l}\text { D } \\
\text { on } \\
\text { U } \\
\text { N } \\
\text { N }\end{array}$ & 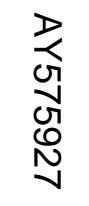 & $\begin{array}{l}D \\
\text { U } \\
\text { Ù } \\
\text { N } \\
\infty\end{array}$ & 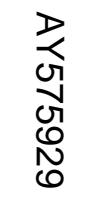 & $\begin{array}{l}D \\
\text { or } \\
\text { J } \\
\text { U్ } \\
\text { Un }\end{array}$ & $\begin{array}{l}\text { D } \\
\text { G } \\
\text { J } \\
\text { E్ }\end{array}$ & 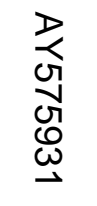 & 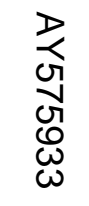 \\
\hline AY575923 & - & 100 & 100 & 100 & 100 & 100 & 100 & 99.6 & 99.6 & 100 & 99.6 \\
\hline AY575924 & 0 & - & 100 & 100 & 100 & 100 & 100 & 99.6 & 99.6 & 100 & 99.6 \\
\hline AY575925 & 0 & 0 & - & 100 & 100 & 100 & 100 & 99.6 & 99.6 & 100 & 99.6 \\
\hline AY575926 & 0 & 0 & 0 & - & 100 & 100 & 100 & 99.6 & 99.6 & 100 & 99.6 \\
\hline AY575927 & 0 & 0 & 0 & 0 & - & 100 & 100 & 99.6 & 99.6 & 100 & 99.6 \\
\hline AY575928 & 0 & 0 & 0 & 0 & 0 & - & 100 & 99.6 & 99.6 & 100 & 99.6 \\
\hline AY575929 & 0 & 0 & 0 & 0 & 0 & 0 & - & 99.6 & 99.6 & 100 & 99.6 \\
\hline AY575932 & 2 & 2 & 2 & 2 & 2 & 2 & 2 & - & 100 & 99.6 & 99.1 \\
\hline AY575930 & 2 & 2 & 2 & 2 & 2 & 2 & 2 & 0 & - & 99.6 & 99.1 \\
\hline AY575931 & 0 & 0 & 0 & 0 & 0 & 0 & 0 & 2 & 2 & - & 99.6 \\
\hline AY575933 & 2 & 2 & 2 & 2 & 2 & 2 & 2 & 4 & 4 & 2 & \\
\hline
\end{tabular}

\section{Discussion}

KomÁreK \& Lund (1990) and DesiKachary \& JEEJI BAi $(1992,1996)$ have described different species of the genus Arthrospira (A. platensis, A. fusiformis, A. jenneri, A. maxima and Arthrospira indica) considering various morphological characters and habitats. According to these features, using light microscopic observations, the Kenyan Arthrospira strains have been recognized as $A$. fusiformis, whereas the calyptrated Indian strains were determined as $A$. indica. Coiling and pitch of the helix are highly variable in the Kenyan and in the Indian strains and are therefore not considered for the species identification of Arthrospira. Spiral trichomes of cyanobacteria can transform to straight filaments but this phenomenon can not be observed the other way round (BAKER 1997). The straight Arthrospira strain PD1998/pus remained unchanged even after several years of being placed in different physical conditions. 
Both helical and straight filaments were observed in Arthrospira strain AB2002/02 during culturing in laboratory. Reversible change from loose helix to tight helix has also been reported (LI et al. 2001). Helix orientation in the cyanobacterium Arthrospira has extensively been studied and found that this feature is not stable and is controlled by environmental conditions, particularly temperature (MÜHLING et al. 2003).

Despite their differences in morphology and habitats, in the 16S and PC-IGS phylogenetic trees all sequences of Kenyan and Indian Arthrospira strains (AY575923-AY575932; AY575937-AY575946) are grouped in a uniform cluster each and in pairs show similarities of $100 \%$. Li et al. (2001) also reported $100 \%$ sequence similarity when investigating the $16 \mathrm{~S}$ rDNA sequences of an Arthrospira maxima strain (AF260509) and Arthrospira fusiformis strain (AF260510). The partial 16S rDNA sequences of both strains match to $100 \%$ with those of our strains. NELISSEN et al. (1994) found a 16S rRNA sequence similarity of two Arthrospira strains (PCC7345 and PCC8005) of 99.7\%. According to CASTENHOLZ et al. (2001) such a high molecular similarity makes it likely that all Arthrospira strains are representatives of only one species. A 16S rRNA gene sequence similarity value of more than $97.5 \%$ is regarded the level at which two bacterial strains can be congeneric or belong to the same species (DEVEREUX et al. 1990, STACKEBRANDT \& GOEBEL 1994). In contrast FoX et al. (1992) have mentioned that 16S rRNA sequences analysis is not necessarily a foolproof criterion to guarantee species identity, because closely related species may not be recognizable with this tool.

The investigation of the PC-IGS locus of Arthrospira strains from different continents has shown a separation in three clusters. No relation to morphology and geographical origin of the strains was found (MANEN \& FALQUET 2002). They suggested horizontal transfers of parts of the sequence responsible for the different clusters. We have found the same division when using the PC-IGS locus for tree construction. The Kenyan and Indian Arthrospira strains (AY575937-AY575946) were included together in one subcluster showing $100 \%$ basepair similarities. The only variations between the studied strains were found in the ITS region. SCHELDEMAN et al. (1999) and BAURAIN et al. (2002) have investigated the ITS regions of several Arthrospira strains, assigned to the species A. fusiformis, A. maxima, A. platensis and A. indica from four continents. According to their results, the strains could be divided into two main clusters with two subclusters each. Like in the investigation of the PC-IGS locus by MANEN \& FALQUET (2002) a clear relationship between ITS clusters and strain denomination, 
morphology or the geographical origin was not found. In the study of BAURAIN et al. (2002), Kenyan Arthrospira strains from L. Nakuru and L. Sonachi could be found in both main clusters. In contradiction to their findings, all our 7 Kenyan Arthrospira strains taken out from 6 alkaline lakes are grouped in one cluster (AY575923-AY575929), that is subcluster IA according to BAURAIN et al. (2002). The Indian strain PD1997/ram (AY575931) also belonged to subcluster IA, whereas the two other Indian strains PD1998/pus and PD2002/ana (AY575930 and AY575932) belonged to subcluster IB with 100\% base pair similarity. PD1998/pus has a straight and PD2002/ana a spiral morphotype.

Like the investigated Arthrospira strains the two Spirulina strains were isolated from an alkaline and a freshwater habitat. The Kenyan alkalitolerant Spirulina strain AB2002/06 and the Indian freshwater strain PD2002/gca have been recognized as S. subsalsa. In the16S and the PC-IGS trees, a Spirulina cluster could be clearly distinguished from the Arthrospira cluster. This supports the earlier findings of NELISSEN et al. (1994) who demonstrated using 16S rDNA sequences that Spirulina sp. PCC6313 is not closely related to Arthrospira. Similar results were obtained from analysis of the phycocyanin locus (MANEN \& FALQUET 2002). The low similarity of only $91.5 \%$ (16S rDNA) between the Indian and Kenyan Spirulina strains shows, that the two strains are not closely related. Inside the Spirulina cluster a separation between the alkalitolerant S. subsalsa strain AB2002/06 (AY575934) from Kenya, the halotolerant Halospirulina (Y18790) and the Indian freshwater S. subsalsa strain PD2002/gca (AY575935) is obvious. MARGHERI et al. (2003) could clearly distinguish separate clusters correlated with habitats, when they investigated Spirulina and Geitlerinema strains from different alkaline, saline and freshwater habitats using ARDRA. They reported that hypersaline and alkaline strains are genetically distinct from the other isolates of marine and fresh water environments. In the present study, alkaline (Kenyan) and fresh water (Indian) strains of Arthrospira with different morphotypes are genetically identical and form a phylogenetically coherent group.

The Phormidium cf. terebriformis strain AB2002/07 was isolated from a phytoplankton sample from Lake Nakuru, the strain KR2003/25 from a less alkaline hot spring at the shore of Lake Bogoria. They are not planktic and grow in culture forming mats on the surface of the culture flask. Morphologically they can be clearly distinguished from the Arthrospira strains. The filaments are slightly undulated. HINDÁK (2001) and KRIENITZ et al. (2003) have described $P$. cf. terebriformis from hot springs at the shore of Lake Bogoria, where it is found 
in mats on the substrate surface together with Spirulina subsalsa, Oscillatoria willei and Synechococus bigranulatus. In the 16S, the PC-IGS and the ITS trees the P. cf. terebriformis strain AB2002/07 (AY575933; AY575947) was always found close to or in the Arthrospira cluster. That makes it evident that it is closely related to Arthrospira. The high similarity values of $99.6 \%$ in the sequences of the $16 \mathrm{~S}$ rDNA and ITS and $98.0 \%$ in the PC-IGS locus support this suggestion (DEvereuX et al. 1990, STACKEBRANDT \& GoEBEL 1994). However, this strain was lacking helicity, a major character of the genus Arthrospira. Because of frequent movements of flamingos between the alkaline lakes in the Rift Valley, it can be suggested that Phormidium cf. terebriformis strains are transported from the hot springs to other lakes. The Lesser Flamingos (Phoeniconaias minor GEOFFROY) use the less saline water of the hot springs for washing themselves and drinking (MARI \& COLLAR 2000, Krienitz et al. 2003). During this procedure filaments and single cells of hot spring cyanobacteria can adhere to their bodies. However, in the 16S tree the Phormidium strain KR2003/25 (AY575936) is clearly separated from the strain AB2002/07 (AY575933), which is supported by a $16 \mathrm{~S}$ similarity of only $92.0 \%$. Both strains are living in habitats with differences in temperature and salinity conditions and most likely they are not members of the same species.

Molecular characterizations of Arthrospira, Spirulina and Phormidium strains in the present study demonstrate that different morphotypes may be genetically similar and vice versa.

\section{Acknowledgements}

We thank the German Federal Ministry of Education and Research for financial support (grant BIOLOG No. 01LC0001). We are grateful to Monika Degebrodt for excellent technical assistance.

\section{References}

AibA, S. \& OGAwA, T. (1977): Assessment of growth yield of a blue green alga: Spirulina platensis, in axenic and continuous culture. J. Gen. Microbiol. 102: 179-182.

ANAGNOSTIDIS K. \& KOMARÉK J. (1985): Modern approach to the classification system of cyanophytes 1 - Introduction. Arch. Hydrobiol./Suppl. 71, Algological Studies 38/39: 291-302.

ANAGNOSTIDIS, K. \& KoMÁREK, J. (1988). Modern approach to the classification system of cyanophytes 3, Oscillatoriales. Arch. Hydrobiol./Suppl. 80, Algological Studies 50/53: 327-472. 
BAKER, P. D. (1997): Occurrence of Cylindrospermopsis in South-Eastern Australia. In: JONES G. (Ed.): Cylindrospermopsis -a new toxic algal bloom challenge for Australia, pp. 5-7. Agricultural and Research Management, Council of Australia and New Zealand Brisbane.

Baurain, D., Renquin, L., Grubisic, S., Scheldeman, P., Belay, A. \& Wilmotte, A. (2002): Remarkable conservation of internationally transcribed spacer sequences of Arthrospira ("Spirulina") (Cyanophyceae, Cyanobacteria) strains from four continents and of recent and 30-year-old dried samples from Africa. J. Phycol. 38: 384-393.

BOYER, S.L.; FleChTNER, V.R. \& JOHANSEN, J.R. (2001): Is the 16S-23S rRNA internal transcribed spacer region a good tool for use in molecular systematics and population genetics? A case study in cyanobacteria. Mol. Biol. Evol. 18: 1057-1069.

CASTEnholz, R.W. (1989): Subsection III, Order Oscillatoriales. In: Staley, J.T, BRYAnt, M.P., Pfennig, N. AND Holt, J.G. (EDS.), Bergey's Manual of Systematic Bacteriology, Vol. 3, pp. 1771-1780, Williams and Wilkins, Baltimore

CASTENHOlz R.W. (2001): General characteristics of the Cyanobacteria. IN: BOONE, D.R. \& CASTEnholz, R.W. (Eds.): Bergey's Manual of Systematic Bacteriolgy. Second edition, Volume 1. The Archaea and the Deeply Branching and Phototrophic Bacteria. pp. 474487, Springer, New York.

Castenholz, R.W., Rippka R., Herdman M. \& Willmotte, A. (2001): Subsection III. (Formerly Oscillatoriales Elenkin 1934). In: BoONE, D.R. \& CASTENHOLZ, R.W. (Eds.) Bergey's Manual of Systematic Bacteriology. Second Edition, Volume 1. The Archaea and the Deeply Branching and Phototrophic Bacteria.Springer, pp. 539-562, Springer, New York.

DESIKACHARY, T.V. (1959): Cyanophyta. Indian Council of Agriculture Research, Monographs on Algae. 686 pp., New Delhi, India.

Desikachary, T.V. \& JeEJi BAI, N. (1992): Taxonomic studies in Spirulina. In: Seshardi, C. V. \& JEEJI BAI, N. (Eds.), Spirulina, ETTA National Symposium, pp. 12-21, MCRC, Madras, India.

DesikaChary, T.V. \& JeEJI BAI, N. (1996): Taxonomic studies in Spirulina II. The identification of Arthrospira ("Spirulina") strains and natural samples of different geographical origins. Algological Studies 83: 163-178.

Devereux, R., He, S.H. Doyle, C.L. Orkland, S. Stahl, D.A. LeGall, J. \& Whitman, W.B. (1990): Diversity and origin of Desulfovibrio species: phylogenetic definition of a family. J. Bacteriol. 172: 3609-3619.

FELSENSTEIN, J. (1981): Evolutionary trees from DNA sequences: a maximum likelihood approach. J. Mol Evol. 17: 368-376.

Fox G.E., WisOtZKeY, K.D. \& JURTSHUK, P. JR. (1992): How close is close: 16S rRNA sequence identity may not be sufficient to guarantee species identity. Int. J. Syst. Bact. 42: 166-170.

GeiTLER L. (1932): Cyanophyceae. In: KolKwITZ R. (Ed.), Dr. L. Rabenhorst's Kryptogamenflora von Deutschland, Österreich und der Schweiz. 1196 pp., Akademische Verlagsgesellschaft Leipzig.

Giovannoni, S.J. Turner, S., Olsen, G.J., Barns, S., LANe, D.J. \& PACE, N.R. (1988): Evolutionary relationships among cyanobacteria and green chloroplasts. J. Bacteriol. 170: 3584-3592.

Guglielmi, G. \& COHEN-BAZIRE G. (1982a): Structure and distribution of pores and perforation of the peptidoglycan wall layer in some cyanobacteria. Protistologica 18: 151166.

Guglielmi, G. \& COHEN-BAZIRE G. (1982b): Comparative study of the structure and 
distribution of the extracellular filaments (fimbriae) in some cyanobacteria. Protistologica 18: $167-178$.

Guglielmi, G., RIPPKA, R. \& TANDEAU DE MARSAC, N. (1993): Main properties that justify the different taxonomic position of Spirulina spp. and Arthrospira spp. among cyanobacteria. Bull. Inst. Oceanogr., Monaco, 12: 13-23.

Hegewald, E., KRIENITZ, L. \& SchnePf, E. (1994): Studies on Scenedesmus costatogranulatus Skuja. Nova Hedwigia 59: 97-127.

HePPERLE, D. (2000): Align, Manual Sequence Alignment Editor for PCs.

. Distributed by the author; available at http:// wwwuser.gwdg.de/ dhepper/

HINDÁK, F. (1985): Morphology of trichomes in Spirulina fusiformis Vorochnin from Lake Bogoria, Kenya. Arch. Hydrobiol./Suppl. 71, Algological Studies 38/39: 201-218.

HINDÁK, F. (2001): Thermal microorganismens from a hot spring on the coast of Lake Bogoria, Kenya. Nova Hedwigia, Beih. 123: 77-93.

Krienitz, L., Ballot, A., Kotut, K., Wiegand, C., Pütz, S., Metcalf, J.S., Codd, G.A. \& PFLUGMACHER, S. (2003): Contribution of hot spring cyanobacteria to the mysterious deaths of Lesser Flamingos at Lake Bogoria, Kenya. FEMS Microbiol. Ecol. 43: 141-148.

KomÁREK, J. \& Lund, J.W. G. (1990): What is 'Spirulina platensis' in fact? Arch. Hydrobiol./Suppl. 85, Algological Studies 58: 1-13.

LI, R. H., DeBElla, H.J., \& CARMICHAEL, W.W. (2001): Isolates identifiable as Arthrospira maxima and Arthrospira fusiformis (Oscillatoriales, Cyanobacteria) appear identical on the basis of a morphological study in culture and 16S rRNA gene sequences. Phycologia 40: $367-371$.

LiTVAitis, M. K. (2002): A molecular test of cyanobacterial phylogeny: inferences from constraint analyses. Hydrobiologia. 468:135-145.

LUDWIG, W. \& SCHLEIFER, K.H. (1994): Bacterial phylogeny based on 16S and 23 S rRNA sequence analysis. FEMS Microbiol. Rev. 15: 155-173.

LUDWIG W. \& KLENK, H.-P. (2001): Overwiew: a phylogenetic backbone and taxonomic framework for prokaryotic systematics. In: BOONE, D.R.\& CASTENHOLZ R.W. (Eds.): Bergey's Manual of Systematic Bacteriology. Second Edition, Volume 1. The Archaea and the Deeply Branching and Phototrophic Bacteria. pp. 49-65, Springer, New York.

MANEN, J.-F. \& FALQUET, J. (2002): The cpcB-cpcA locus as a tool for the genetic characterization of the genus Arthrospira (Cyanobacteria): evidence for horizontal transfer. Int. J. System. Evol. Microbiol. 52: 861-867.

Margheri, M. C., PicCARdi, R., Ventura, S., Viti, C. \& Giovannetti, L. (2003): Genotypic diversity of oscillatoriacean strains belonging to the genera Geitlerinema and Spirulina determined by 16S rDNA restriction analysis. Curr. Microbiol. 36. 359-364.

MARI, C. \& COLlaR, N (2000): Pink Africa, 207 pp. Harvill, London.

MÜHLING, M., HARRIS, N., BElAy, A. \& WhitTon, B. A. (2003). Reversal helix orientation in the cyanobacterium Arthrospira. J. Phycol. 39: 360-367.

NCBI (National Center for Biotechnological Information) (2003): available at http://www.ncbi.nlm.nih.gov

NeIlan, B.A., JACOBS, D. \& GoODMAN, A. (1995): Genetic diversity and phylogeny of toxic cyanobacteria determined by DNA polymorphisms within the phycocyanin locus. Appl. Environ. Microbiol. 6: 3875-3883.

Nelissen, B., Wilmotte, A., Neefs, J.-M. \& De Wachter, R. (1994): Phylogenetic relationships among filamentous helical cyanobacteria investigated on the basis of $16 \mathrm{~S}$ ribosomal RNA gene sequence analysis. System. Appl. Microbiol. 17: 206-210. 
Nelissen, B., De BAere, R., Wilmotte, A. \& De W Achter, R. (1996): Phylogenetic relationships of nonaxenic filamentous cyanobacterial strains based on 16S rRNA sequence analysis. J. Mol. Evol. 42:194-200.

NÜBEL, U. F. GARCIA PICHEL \& MUYZER, G. (1997): PCR primers to amplify 16S RRNA genes from cyanobacteria. Appl. Environ. Microbiol. 63: 3327-3332.

OLSEN, G.J. and WOESE, C.R. (1993): Ribosomal RNA: a key to phylogeny. FASEB J. 7: 113-123.

Olsen, G.J., MAtsuda, H., HAgstrom, R. \& Overbeck, R. (1994): fastDNAml: a tool for construction of phylogenetic trees of DNA sequences using maximum likelihood. Comp. Appl. Biosc. 10: 41-48.

Rippka, R., Deruelles, J., WATERbury, J. B., Herdman, M. \& StAnier, R. Y. (1979): Generic assignments, strain histories and properties of pure cultures of cyanobacteria. J. Gen. Microbiol. 111, 1-61.

RIPPKA, R., CASTENHOLZ, R.W. \& HERDMAN, M. (2001): Subsection IV. (Formerly Nostocales (Castenholz 1989b sensu Rippka, Deruelles, Waterbury, Herdman and Stanier 1979). In: Boone, D.R. \& CAStenholz, R.W. (Eds.): Bergey's Manual of Systematic Bacteriology. Second Edition, Volume 1. The Archaea and the Deeply Branching and Phototrophic Bacteria. pp. 562-589, Springer, New York.

Scheldeman, P., Baurain, D., Bouhy, R., Scott, M., Mühling, M., Whitton, B.A., Belay, A. \& WilmotTe, A. (1999): Arthrospira ("Spirulina") strains from four continents are resolved into only two clusters, based on amplified ribosomal DNA restriction analysis of the internally transcribed spacer. FEMS Microbiology Letters 172: 213-222.

SCHLÖSSER, U. G. (1994): SAG-Sammlung von Algenkulturen at the University of Göttingen. Catalogue of Strains 1994. Bot. Acta 107: 113-186.

STACKEBRANDT, E. \& GoEBEL, B. M. (1994): Taxonomic note: a place for DNA-DNA reassociation and $16 \mathrm{~S}$ rRNA sequence analysis in the present species definition and bacteriology. Int. J. Bacteriol. 44: 846-849.

TOMASElli, L., PALANDRI, M. R. \& TREDICI, M. R. (1996): On the correct use of the Spirulina designation. Algological Studies 83: 539-548.

TOMASELli, L. (1997): Morphology, ultrastructure and taxonomy of Arthrospira (Spirulina) maxima and Arthrospira (Spirulina) platensis. In: VonsHAK, A. (Ed.), Spirulina platensis (Arthrospira). Physiology, Cell-Biology and Biotechnology, pp. 1-17. Taylor and Francis, London.

WilmotTe, A. (1994): Molecular evolution and taxonomy of cyanobacteria. In: Bryant, D.A. (Ed.), The Molecular Biology of Cyanobacteria. pp.1-25, Kluwer, Dordrecht.

Wilmotte, A. \& HeRdMAN, M. (2001): Phylogenetic relationships among the cyanobacteria based on 16S rRNA sequences. In: BoOne, D.R. \& CASTENhOlZ R.W. (Eds.), Bergey's Manual of Systematic Bacteriology. Second Edition, Volume 1. The Archaea and the Deeply Branching and Phototrophic Bacteria. pp. 487-493, Springer, New York. WoESE, C.R. (1987): Bacterial evolution. Microbial Rev. 51: 221-271. 